\title{
Sources of organic matter for intertidal consumers on Ascophyllum-shores (SW Iceland): a multi-stable isotope approach
}

\author{
G. Sarà · M. De Pirro · C. Romano · P. Rumolo • \\ M. Sprovieri · A. Mazzola
}

Received: 19 September 2006 / Revised: 24 July 2007 / Accepted: 24 July 2007 / Published online: 15 August 2007

(C) Springer-Verlag and AWI 2007

\begin{abstract}
Stable isotopes were used to examine the origin of organic matter in Icelandic Ascophyllum-based habitats, the role of different organic matters in filling intertidal food webs and the food preferences of the most abundant suspension feeders, grazers and predators. We selected three intertidal sites on the SW coast of Iceland where we sampled in early September 2004, organic matter sources (POM, SOM and most abundant primary producers, $A$. nodosum and $F$. vesciculosus) and the most abundant macrofauna species (barnacles, mussels, gastropods, sponge and crabs). Even though the primary production (Ascophyllum-based) was the same at the three study sites, the isotopic composition of common-among-sites organisms varied due to local differences in the origin of available POM and SOM and in food web structures.
\end{abstract}

Keywords Benthic organism - Intertidal environment . Stable isotope $\cdot$ Iceland $\cdot$ North Atlantic

Communicated by H.-D. Franke.

G. Sarà $(\bowtie) \cdot$ A. Mazzola

Dipartimento di Biologia Animale, Università di Palermo,

Via Archirafi, 18, 90123 Palermo, Italy

e-mail: gsara@unipa.it

M. De Pirro

Dipartimento di Biologia Animale e Genetica,

Università di Firenze, Via Romana 17, 50100 Firenze, Italy

C. Romano

IAMC-CNR-IRMA, Via da Terrazzano,

17, 91011 Castellammare del Golfo, Italy

P. Rumolo $\cdot$ M. Sprovieri

IAMC-CNR, Calata Porta di Massa - 80133 Porto di Napoli,

Napoli, Italy

\section{Introduction}

The intertidal habitats of the North Atlantic rocky seashores are among the most studied environments in the northern hemisphere (Raffaelli and Hawkins 1996; Widdows 2001). Their most characteristic macroalgae are Ascophyllum nodosum and Fucus spp. (Hansen and Ingólfsson 1993; Espinosa and Guerra-Garcia 2005). The food supply for benthic macrofauna is strongly influenced by tidal processes, which are responsible for the active transport of organic matter, mainly of macro-algal origin. Although ecological studies on single organisms from the northern intertidal are abundant (Tomanek and Helmuth 2002), little is known on organic matter sources for the key macrofauna species of these habitats. Some studies have revealed distinct differences in trophic pathways in these ecosystems, relating to biogeographical conditions (Ingólfsson 1992) or anthropogenic factors (Riera and Nieuwenhuize 2004). Thus, although some general ecological patterns can be recognised for the intertidal habitats of the northern hemisphere, special local conditions can lead to ecological scenarios, which vary from the norm (sensu Ingólfsson 1992). Examples are tidal Ascophyllum-based shores in polluted waters (Cole et al. 2004; Riera and Nieuwenhuize 2004), and shores under strong influence of inland waters (Page and Lastra 2003). To date, however, no data are available from very pristine environments such as those found on SW coasts of Iceland, where human action is rather limited and the tidal regime is very constant among sites. In the present study, we used the isotopic approach to investigate the trophic functioning of Icelandic rocky shore communities. Specifically, we selected three different sites to study: (1) the origin of organic matter in Ascophyllum-based habitats, (2) the role of different organic 
matters in filling intertidal food webs, and lastly (3) the food preferences of the most abundant suspension feeders, grazers and predators.

\section{Materials and methods}

Study sites

Three sites were selected on the SW coast of Iceland, close to the Sandgerdi Marine Centre $\left(64^{\circ} 02^{\prime} 26^{\prime \prime} \mathrm{N}\right.$; $22^{\circ} 42^{\prime} 49^{\prime \prime} \mathrm{W}$ ): the Osar bay located eastward of Sandgerdi; Hvassahraun and the Reykjavik old harbour, both situated westward of Sandgerdi (Fig. 1). Osar and Hvassahraun were distant from densely populated areas, and therefore the community structure at both sites was assumed to be controlled largely by natural biological and physical factors (Espinosa and Guerra-Garcia 2005). Both these sites were far from freshwater inlets and had similar tidal ranges (2.5$3.8 \mathrm{~m}$ ) at spring tides (Ingòlfsson 1992, 1996); the water temperature was about $10.0-11.5^{\circ} \mathrm{C}$ and the salinity at marine levels (but see http://www.hafro.is). Reykjavik harbour was polluted by miscellaneous human activities although scientific data are lacking; the substrata in the intertidal were substantially artificial.

\section{Data collection and analysis}

Samplings were carried out in early September 2004. At each study site, we selected different hard substrata (natural rocks in Osar and Hvassahraun and artificial substrate in Reykjavik harbour) abundantly colonised by Ascophyllum nodosum, which is the main primary producer in the area (Espinosa and Guerra-Garcia 2005). From each site, dominant macroalgae (Ascophyllum nodosum [Linnaeus]
Le Jolis; Fucus vesciculosus Linnaeus) were collected by hand, and epiphytic material was removed from the thalli by gentle scraping. The first centimetre of sediment in the intertidal (in Osar and Hvassahraun only) was taken by small corers $(\emptyset=4 \mathrm{~cm})$ to determine the origin of the sedimentary organic matter (SOM). Samples of seawater both from the Sandgerdi offshore area (as true marine referential signal) and each sampling site were collected in 41 glass bottles; the water was filtered through precombusted $\left(450^{\circ} \mathrm{C}, 4 \mathrm{~h}\right)$ Whatman $\mathrm{GF} / \mathrm{F}$ filters for the isotopic analysis of the particulate organic matter (POM). All organisms abundantly found at all sites according to Espinosa and Guerra-Garcia (2005) were collected manually: the gastropods Littorina obtusata (Linnaeus, 1758), Buccinum sp., Linnaeus 1758, and Nucella lapillus (Linnaeus, 1758), the bivalve Mytilus edulis Linnaeus, 1758, the decapods Carcinus maenas (Linnaeus, 1758), the barnacle Semibalanus balanoides (Linnaeus, 1758), the sponge Halichondria panicea (Pallas, 1766) and starfish Leptasterias muelleri (M.Sars, 1846). Having been cleared of epiphytes, the animals were kept alive in filtered seawater for at least $24 \mathrm{~h}$ to allow for gut evacuation. After acidification $(2 \mathrm{~N} \mathrm{HCl})$, all samples ( $\mathrm{POM}$, SOM, primary organic matter sources and macrofauna) were dried at $60^{\circ} \mathrm{C}$ for several hours (from 24 to $72 \mathrm{~h}$ depending on substrate) and ground with a pestle and mortar (Abed-Navandi and Dworschak 2005). The isotopic analyses were performed using a Finnigan Delta-S isotope ratio mass spectrometer. Isotopic values were expressed in parts per thousand as deviations from standards (Peedee belemnite limestone for $\delta^{13} \mathrm{C}$ and nitrogen in air for $\left.\delta^{15} \mathrm{~N}\right): \quad \delta^{13} \mathrm{C}$ or $\delta^{15} \mathrm{~N}=\left[\left(\mathrm{R}_{\text {sample }} / \mathrm{R}_{\text {standard }}\right)\right.$ $-1] \times 10^{3}$, where $\mathrm{R}={ }^{13} \mathrm{C} /{ }^{12} \mathrm{C}$ or ${ }^{15} \mathrm{~N} /{ }^{14} \mathrm{~N}$. The $t$-student was used to test for differences in isotopic values (Sokal and Rohlf 1981).
Fig. 1 Map of Iceland indicating study sites

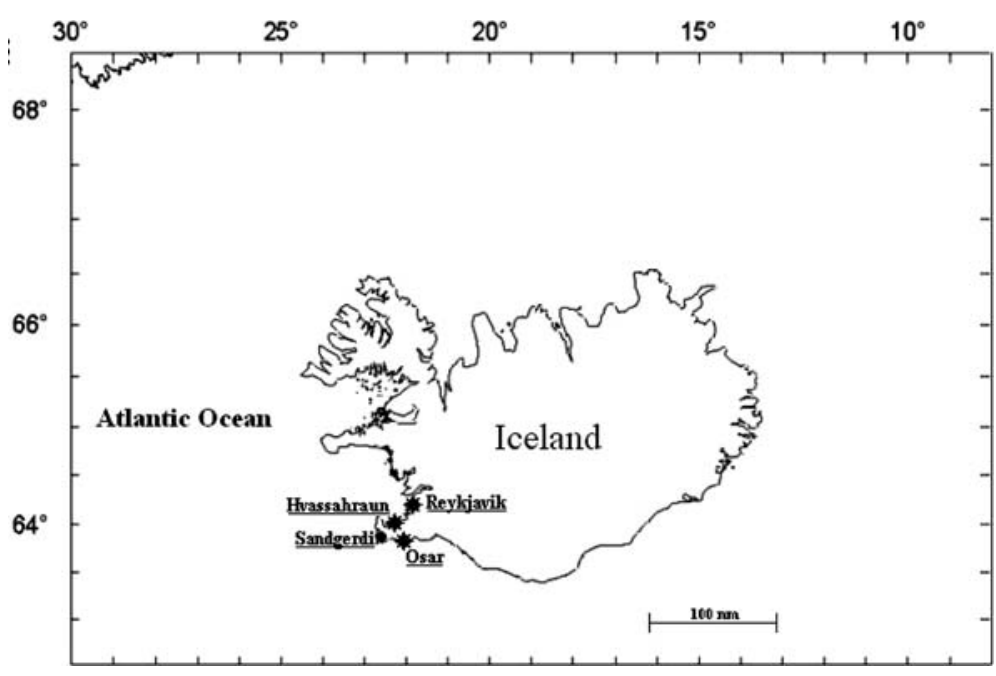




\section{Results and discussion}

Food webs in the three study sites differed with regard to both the trophic base and the apical values (Figs. 2, 3, 4). The trophic base was represented by SOM and POM. SOM was not sampled in Reykjavik harbour; in Osar, SOM carbon was more depleted than in Hvassahraun $(-19.4 \pm 0.2 \%$ and $-16.5 \pm 0.3 \%$, respectively; $P<0.05)$, while nitrogen showed an inverse pattern $(5.7 \pm 0.1 \% \circ$ and $5.1 \pm 0.3 \%$, respectively). The POM carbon ranged between depleted values in Osar $(-22.2 \pm 0.1 \%$; $n=5)$ to less negative values in Hvassahraun $(-17.5 \pm 0.1 \%$; $n=5$; $P<0.05)$. The nitrogen values were very similar at all three sites $(P>0.05)$, ranging from 5.8/5.9 $( \pm 0.9 \% 0)$ in Osar and Reykjavik harbour to $6.7( \pm 0.4 \%$; $n=5)$ in Hvassahraun. The POM carbon depletion found in Osar suggests a certain contribution to the isotopic composition from terrestrial organic matter (Haines and Montague 1979). In Reykjavik harbour the POM appeared to be composed mostly of phytoplankton, while a major contribution from intertidal nearshore organic matter was evident in Hvassahraun. In contrast, SOM in Osar was closely related with $F$. vesciculosus, while in Hvassahraun it appeared to be outside the macroalgae pathway. All of these values suggest that the origins of SOM and POM varied widely as a function of locality, although the main producers were the same at all sites, i.e. $A$. nodosum and $F$. vesciculosus. In contrast, isotopic values of both macro-algae did not vary as widely among sites $(P>0.05)$ as did those of POM and SOM. A. nodosum carbon ranged around $-17.0( \pm 0.6 \%)$, while nitrogen had a mean value of $7.7( \pm 0.2 \%$ ) . In $F$. vescicolosus, too, the isotopic signals were rather stable $\left(\delta^{13} \mathrm{C}=-17.3 \pm 1.9 \%\right.$; $\delta^{15} \mathrm{~N}=6.0 \pm 0.3 \%$ ). This indicates that the same $\mathrm{CO}_{2}$ reservoir is exploited by macroalgae regardless of location,

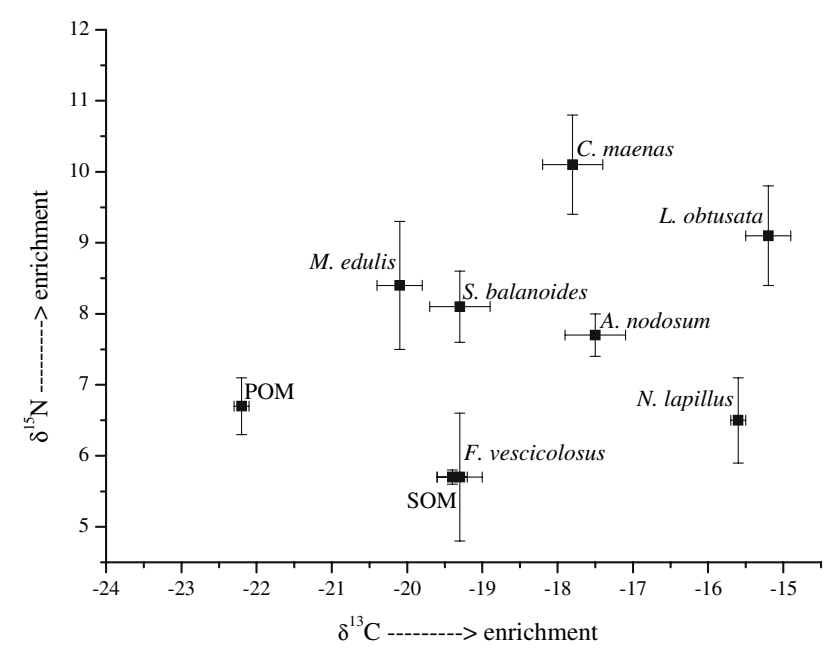

Fig. 2 Biplot $\left(\delta^{13} \mathrm{C}-\delta^{15} \mathrm{~N}\right)$ of isotopic compositions of all organisms sampled in Osar

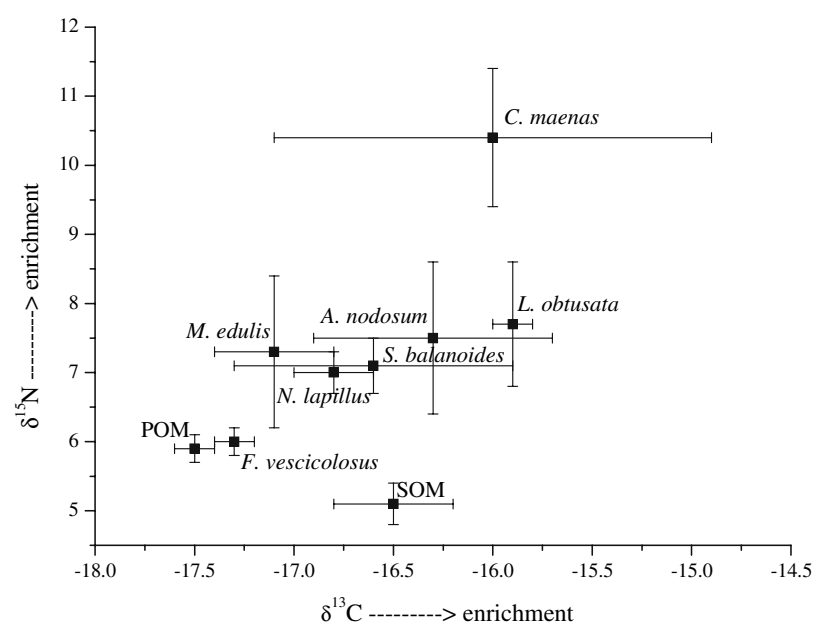

Fig. 3 Biplot $\left(\delta^{13} \mathrm{C}-\delta^{15} \mathrm{~N}\right)$ of isotopic compositions of all organisms sampled in Hvassahraun

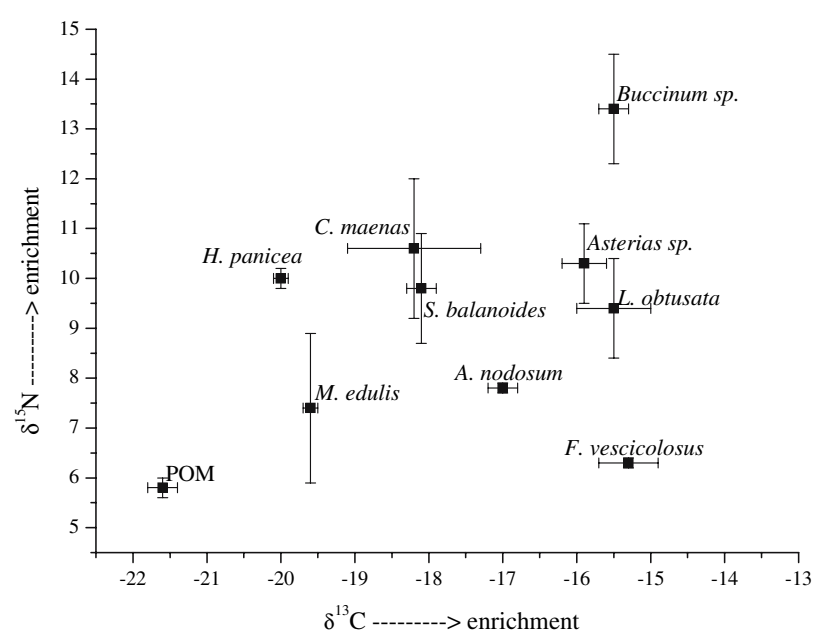

Fig. 4 Biplot $\left(\delta^{13} \mathrm{C}-\delta^{15} \mathrm{~N}\right)$ of isotopic compositions of all organisms sampled in Reykjavik old harbour

and that rhythms of emersion due to tides were similar (sensu Cooper and McRoy 1988; Criss 1999). The isotopic values of the present study concur with ranges given in the literature (Lesage et al. 2001; Adin and Riera 2003). Therefore, even though the primary production (Ascophyllum-based) at the three Icelandic sites was the same, local differences in food web structure arose from varying origins of available POM and SOM. High levels of variability in isotopic patterns among sites subjected to similar ecological constraints have been described previously (e.g. Jennings et al. 1997) and are consistent with the high variability of the intertidal habitats at high latitudes of the northern hemisphere (Ingólfsson 1992). Intertidal habitats are not uniform from a trophic point of view, because tides and local hydrodynamics produce site-specific physical movements, which can transport, at different scales, various types of organic matter (i.e. marine, terrestrial, estuarine). 
In the Ascophyllum-based food webs of the Icelandic coasts, suspension feeders were mostly represented by bivalves and barnacles, the most abundant taxa in these environments (Espinosa and Guerra-Garcia 2005). At all three sites, mussels and barnacles relied directly on POM. $M$. edulis had a more depleted carbon composition $(P>0.05)$ at all sites (Osar $\delta^{13} \mathrm{C}=-20.1 \pm 0.3 \% ; n=30$; Hvassahraun $\left(\delta^{13} \mathrm{C}=-17.1 \pm 0.3 \%\right.$; $n=30$; Reykjavik harbour $\left(\delta^{13} \mathrm{C}=-19.6 \pm 0.1 \%\right.$; $\left.\quad n=30\right)$, suggesting a greater dependence on POM, than S. balanoides (Osar $\delta^{13} \mathrm{C}=$ $-19.3 \pm 0.4 \%$; $n=50 ;$ Hvassahraun $\left(\delta^{13} \mathrm{C}=-16.6 \pm 0.7\right.$ $\%$; $n=50 ; \quad$ Reykjavik harbour $\left(\delta^{13} \mathrm{C}=-18.1 \pm 0.2 \%\right.$; $n=50$ ), in which carbon appeared to be dependent on macroalgae-SOM detritus. The same pattern was also evident for nitrogen. Mussels in Osar and Hvassahraun were slightly more enriched in ${ }^{15} \mathrm{~N}$ than barnacles $(7.3 \pm 1.1 \%$ vs $7.1 \pm 0.4 \%$ o, in Osar, and $8.4 \pm 0.9 \%$ ov $8.1 \pm 0.5 \%$ o, in Hvassahraun), while in Reykjavik harbour nitrogen values were significantly lower in mussels than in barnacles (7.4 $\pm 1.5 \%$ vs $9.8 \pm 1.1 \%$; $P<0.05)$. Thus, organic matter of off- and nearshore marine origin represented the most important food source for both organisms, with SOM representing an important part of the assimilated fraction. However, as POM in these habitats showed mostly sedimentary signatures, it would seem that these intertidal Icelandic filter feeders ultimately rely on a detrital mixture originating from terrestrial, macro-algal, phytoplanktonic and likely microphytobenthic sources (i.e. mostly diatoms, which were not sampled in the present study). This result is consistent with recent findings, demonstrating that organic matter of sedimentary origin can be an important component in the diets of many marine suspensivores (Mann 1988; Langdon and Newell 1990; Sarà et al. 2002, 2003; Sarà 2006), and contradicting the view that phytoplankton is the greatest (or even only) dietary component in coastal habitats (Newell 1979; Loo and Rosenberg 1989). Only in Reykjavik harbour we found extended hard surfaces colonised by a further suspension feeder, the sponge Halichondria panicea. Its $\left(\delta^{13} \mathrm{C}\right.$ value was slightly more negative $(-20.0 \pm 0.1 \%$ o than the values of mussels and barnacles, while the sponge enriched in ${ }^{15} \mathrm{~N}(10.0 \pm 0.2 \%$ o. The increased frequency of sponges in the harbour, compared to the "clean" sites, suggests the presence of a finer fraction of detritus strongly colonised by bacteria (Coma et al. 2001) as it is typically found in polluted sites. The different isotopic compositions of the sponge indicates that each sessile filter feeder consumes a broad spectrum of seston fractions in proportion to their availability (Coma et al. 2001).

The grazing function was mostly represented by the snail L. obtusata, the most abundant gastropod taxon. L. obtusata's isotopic composition showed a strong dependence on A. nodosum-derived OM, above all for carbon (Osar $\delta^{13} \mathrm{C}=-15.2 \pm 0.3 \%$; $n=20$; Hvassahraun $\left(\delta^{13} \mathrm{C}=\right.$
$-15.9 \pm 0.1 \% ; \quad n=20 ; \quad$ Reykjavik harbour $\left(\delta^{13} \mathrm{C}=\right.$ $-15.5 \pm 0.3 \% ; n=20$ ). With regard to nitrogen, however, isotopic values were quite and almost site-specific (Osar $\delta^{15} \mathrm{~N}=9.1 \pm 0.7 \%$; $n=20 ;$ Hvassahraun $\left(\delta^{15} \mathrm{~N}=7.7 \pm\right.$ $0.9 \% ; \quad n=20 ;$ Reykjavik harbour $\delta^{15} \mathrm{~N}=9.4 \pm 1.0 \%$; $n=20)$. The values of $\left(\delta^{13} \mathrm{C}(-15.0 /-16.0 \%\right.$ at all sites $)$ showed that snails relied very strongly on A. nodosum carbon, while the wide variation of nitrogen values among sites suggests that the source of nitrogen varies as a function of local availability. Although our isotopic findings predict that snails mainly rely on Ascophyllum organic matter, L. obtusata in the Sandgerdi area has also been reported to feed on small propagules and spores of Fucus spp. (Espinosa and Guerra-Garcia 2005). In any case, our isotopic frame is consistent with the view that snails are usually specialist grazers on macroalgae and associated epiphytic components (Riera et al. 2000), which highlight a strong dependence of Littorina spp. on algae (Williams 1990; Albrecht and Reise 1994).

The other ecological function investigated in the present paper was that of benthic predators. At all study sites, the most abundant benthic predator was the green crab C. maenas. Other predators, such as the gastropods Buccinum sp., $N$. lapillus and the starfish Asterias sp., were infrequent in Osar and Hvassahraun, but abundant in Reykjavik harbour. These observations are consistent with the only published study on the intertidal benthos of Iceland (Espinosa and Guerra-Garcia 2005). However, we sampled neither intertidal fish (we sampled only on rocky) nor shorebirds such as plovers or sandpipers, although it is likely that shorebirds, in particular, are the 'real' top predators in these habitats, which are able to actively export secondary intertidal organic matter to adjacent ecosystems (Thompson et al. 1999). Among the active predators N. lapillus, normally believed to prey on mussels and snails (Hughes and Durwett 1985), showed in both Osar and Hvassahraun, an isotopic frame that was incompatible with the most commonly accepted view. Indeed, its mean $\delta^{13} \mathrm{C}$ values of -16.2 $( \pm 0.8 \% o)$ and mean $\left(\delta^{15} \mathrm{~N}\right.$ values of $6.7( \pm 0.3 \%$ ) were more compatible with a dependence on primary and sedimentary organic matter (mostly in Hvassahraun) than with a mussel diet. More research is needed to solve this evident discrepancy. Asterias sp., collected only from Reykjavik harbour, had $\delta^{13} \mathrm{C}$ values of $-15.9( \pm 0.3 \%$; $n=3)$ and $\left(\delta^{15} \mathrm{~N}\right.$ values of $10.3( \pm 0.8 \%$; $n=3)$, while Buccinum sp. represented the top predator showing $\delta^{13} \mathrm{C}$ values of -15.5 $( \pm 0.2 \%$; $n=3)$ and $\delta^{15} \mathrm{~N}$ values of $13.4( \pm 1.1 \%$; $n=3)$. Seastar isotopic composition was compatible with a diet based on mussels, and buccinids appeared to be strictly carnivorous (Hughes and Durwett 1985; Saier 2001). The diet of the North Atlantic species Buccinum undatum consists of polychaete worms, bivalves, sea urchins and the remains of bivalves killed by seastars (Ilano et al. 2005). The green 
crab appeared to be the general top predator in the absence of Buccinum sp. It is well known as a voracious carnivore, feeding on mussels, clams, snails, worms, barnacles, seaweed, isopods and other crustaceans (Hardwick-Witman 1985; le Roux et al. 1990; Smallegange and van de Meer 2003). Our results supported this view, as $C$. maenas $\left(\delta^{13} \mathrm{C}\right.$ values at all sites, ranging from $-16.0( \pm 1.1 \%$; $n=7)$ in Hvassahraun to $-18.2( \pm 0.9 \%$; $n=8)$ in Reykjavik harbour $(P<0.05)$, demonstrated an assimilation of carbon from a mixture of bivalves, barnacles, snails and SOM. Green crab nitrogen signatures, similar at all sites (Osar $\delta^{15} \mathrm{~N}=10.1 \pm 0.7 \% ; ; n=7 ;$ Hvassahraun $\left(\delta^{15} \mathrm{~N}=10.1 \pm\right.$ $1.0 \% ; n=7$; Reykjavik harbour $\delta^{15} \mathrm{~N}=10.6 \pm 1.4 \%$; $n=8$ ), were also compatible both with this view and with the crab apical role in the Icelandic intertidal food webs.

\section{Concluding remarks}

The Ascophyllum-based intertidal communities of SW Iceland appear to be highly variable in trophic structure. Although the investigated sites are exposed to the same physical factors (i.e. tidal ranges, salinity and temperature) and have the same primary producers at their base, the isotopic composition of common-among-sites organisms varied as a function of local conditions. Particularly in Reykjavik harbour this composition was likely constrained by local pollution, although detailed information on the type and amount of pollution for this site is missing. However, the results are in line with recent literature data showing that organisms in coastal food webs have different isotopic signatures as a function of locality (Deegan and Garritt 1997; Riera and Nieuwenhuize 2004), and that at each site the isotopic frames can also vary on small to medium spatial scales (Jennings et al. 1997). The isotopic compositions of Icelandic organisms largely corresponded to those from other Atlantic areas, with the exception of $N$. lapillus (Hughes and Durwett 1985). The structure of intertidal Ascophyllum-based food webs on hard substrate in Iceland seems to be very simple, being based on a few functions, among which suspension feeding and grazing are the most frequent and best represented. Top predators are represented by a few taxa, and particularly $C$. maenas. At all sites, organic matter from $A$. nodosum, although directly exploited only by some grazing specialists, together with organic matter from $F$. vesciculosus, can flow along the food web, reaching the top predators via predation or scavenging. This findings support the idea that macroalgal organic matter can determine isotopic signatures of coastal organisms (Mann 1988; Page 1997), and that SOM plays a central role in these highly dynamic habitats (Pusceddu et al. 2003; Sarà 2006). Indeed, SOM represents the true collector of all types of locally produced organic matter, that due to hydrodynamics (e.g. tides, lateral drifting, water currents) can be re-distributed to the overlying biota (Pusceddu et al. 1999; Sarà 2006).

Acknowledgments We are very grateful to Dr. Gudmundur Vidir Helgason for arrangements, help and hospitality during our stay at the Sandgerdi Marine Centre (SMC), Iceland, and for making available the invertebrate collections from the international BIOICE project (Benthic Invertebrates of Icelandic waters). Thanks are also due to our friend and colleague Dr. Haldor Palmar Haldorsson and all the staff of the SMC for their kindness and help. The stay at the SMC was supported by the programme "Improving Human Potential: Access to Research Infrastructure", (IHP/ARI) provided by the European Community.

\section{References}

Abed-Navandi D, Dworschak PC (2005) Food source of tropical thalassinidean shrimps: a stable isotope study. Mar Ecol Prog Ser 291:159-168

Adin R, Riera P (2003) Preferential food source utilization among stranded macroalgae by Talitrus saltator (Amphipod, Talitridae): a stable isotopes study in the northern coast of Brittany (France). Estuar Shelf Coast Sci 56:91-98

Albrecht A, Reise K (1994) Effects of Fucus vesiculosus covering intertidal mussel beds in the Wadden Sea. Helgol Meeresunters 48:243-256

Cole ML, Valiela I, Kroeger KD, Tomasky GL, Cebrian J, Wigan C, McKinney RA, Grady SP, Carvahlo da Silva MH (2004) Assessment of a $\delta^{15} \mathrm{~N}$ isotopic method to indicate anthropogenic eutrophication in aquatic ecosystems. J Environ Qual 33:124-132

Coma R, Ribes M, Gili JM, Hughes RN (2001) The ultimate opportunists: consumers of seston. Mar Ecol Prog Ser 219:305-308

Cooper LW, McRoy CP (1988) Stable carbon isotope ratio variations in marine macrophytes along intertidal gradients. Oecologia 77:238-241

Criss RE (1999) Principles in stable isotope distribution. Oxford University Press, New York

Deegan LA, Garritt RH (1997) Evidence for spatial variability in estuarine food webs. Mar Ecol Prog Ser 147:31-47

Espinosa F, Guerra-Garcia JM (2005) Algae, macrofaunal assemblages and temperature: a quantitative approach to intertidal ecosystems of Iceland. Helgol Mar Res 59:273-885

Haines EB, Montague CL (1979) Food sources of estuarine invertebrates analyzed using ${ }^{13} \mathrm{C} /{ }^{12} \mathrm{C}$ ratios. Ecology 60:48-56

Hansen JR, Ingólfsson A (1993) Patterns in species composition of rocky shore communities in sub-arctic fjords of eastern Iceland. Mar Biol 117:469-481

Hardwick-Witman MN (1985) Biological consequences of ice rafting in a New England salt marsh community. J Exp Mar Biol Ecol 87:283-298

Hughes RN, Durwett D (1985) A comparison of the foraging behaviour of dogwhelks, Nucella lapillus (L.), feeding on barnacles or mussels on the shore. J Moll Stud*** 51:73-77

Ilano AS, Miranda MRT, Fujinaga K, Nakao S (2005) Feeding behavior and food consumption of Japanese whelk, Buccinum isaotakii (Neogastropoda: Buccinidae). Fish Sci 71:342-349

Ingòlfsson A (1992) The origin of the rocky shore fauna of Iceland and the Canadian Maritimes. J Biogeogr 19:705-712

Ingòlfsson A (1996) The distribution of intertidal macrofauna of the coasts of Iceland in relation to temperature. Sarsia 81:29-44

Jennings S, Renones O, Morales-Nin B, Polunin NVC, Moranta J, Coll $\mathrm{J}$ (1997) Spatial variation in the ${ }^{15} \mathrm{~N}$ and ${ }^{13} \mathrm{C}$ stable isotope 
composition of plants, invertebrates and fishes on Mediterranean reefs: implications for the study of trophic pathways. Mar Ecol Prog Ser 146:109-116

Langdon CJ, Newell RIE (1990) Utilization of detritus and bacteria as food sources by two bivalve suspension-feeders, the oyster Crassostrea virginica and the mussel Geukensia demissa. Mar Ecol Prog Ser 58:299-310

le Roux PJ, Branch GM, Joska MAP (1990) On the distribution, diet and possible impact of the invasive European shore crab Carcinus maenas (L.) along the South African coast. S Afr J Mar Sci 9:8593

Lesage V, Hammill MO, Kovacs KM (2001) Marine mammals and the community structure of the Estuary and Gulf of St Lawrence, Canada: evidence from stable isotope analysis. Mar Ecol Prog Ser 210:203-221

Loo LO, Rosenberg R (1989) Bivalve suspension-feeding dynamics and benthic-pelagic coupling in a eutrophicated marine bay. J Exp Mar Biol Ecol 130:253-276

Mann KH (1988) Production and use of detritus in various freshwater, estuarine and coastal marine ecosystems. Limnol Oceanogr 33:910-930

Newell RC (1979) Biology of intertidal animals, 3rd edn. Marine Ecological Surveys Ltd, Faversham Kent

Page HM (1997) Importance of vascular plant and algal production to macro-invertebrate consumers in a southern California salt marsh. Estuar Shelf Coast Sci 45:823-834

Page HM, Lastra M (2003) Diet of intertidal bivalves in the Ria de Arosa (NW Spain): evidence from stable $\mathrm{C}$ and $\mathrm{N}$ isotope analysis. Mar Biol 143:519-532

Pusceddu A, Sarà G, Armeni M, Fabiano M, Mazzola A (1999) Seasonal and spatial changes in sediment organic matter composition of a semi-enclosed marine system (W-Mediterranean Sea). Hydrobiologia 397:59-70

Pusceddu A, Dell'Anno A, Danovaro R, Manini E, Sarà G, Fabiano M (2003) Enzymatically hydrolyzable protein and carbohydrate sedimentary pools as indicators of the trophic state of 'detritus sink' systems: a case study in a Mediterranean coastal lagoon. Estuaries 26:641-650

Raffaelli D, Hawkins S (1996) Intertidal ecology. Chapman and Hall, London
Riera P, Nieuwenhuize J (2004) Utilization of food sources by invertebrates in a man-made intertidal ecosystem (Westerschelde, the Netherlands): a $\delta^{13} \mathrm{C}$ and $\delta^{15} \mathrm{~N}$ study. J Mar Biol Assoc UK 84:323-326

Riera P, Stal LJ, Nieuwenhuize J (2000) Heavy $\delta^{15} \mathrm{~N}$ in Intertidal Benthic Algae and Invertebrates in the Scheldt Estuary (The Netherlands): Effect of River Nitrogen Inputs. Estuar Shelf Coast Sci $51: 365-372$

Saier B (2001) Direct and in direct effects of seastars Asterias rubens on mussel beds (Mytilus edulis) in the Wadden Sea. J Sea Res 46:29-42

Sarà G (2006) Hydrodynamic effect on the origin and quality of organic matter for bivalves: an isotopic, biochemical and transplant integrated study. Mar Ecol Prog Ser 328:65-73

Sarà G, Vizzini S, Mazzola A (2002) The effect of temporal changes and environmental trophic condition on the isotopic composition $\left(\delta^{13} \mathrm{C}\right.$ and $\left.\delta^{15} \mathrm{~N}\right)$ of Atherina boyeri (Risso, 1810) and Gobius niger (L., 1758) in a Mediterranean coastal lagoon (Lake of Sabaudia): implications for food web structure. PSZNI Mar Ecol 23:352-360

Sarà G, Vizzini S, Mazzola A (2003) Sources of carbon and dietary habits of new Lessepsian entry Brachidontes pharaonis (Bivalvia, Mytilidae) in the western Mediterranean. Mar Biol 143:713-722

Smallegange IM, van der Meer J (2003) Why do shore crabs not prefer the most profitable mussels? J Anim Ecol 72:599-607

Sokal R, Rohlf FJ (1981) Biometry. WH Freeman and Co., New York

Thompson DR, Lilliendahl K, Solmundsson J, Furness RW, Waldron S, Phillips RA (1999) Trophic relationships among six species of Icelandic seabirds as determined through stable isotope analysis. Condor 101:898-903

Tomanek L, Helmuth B (2002) Physiological ecology of rocky intertidal organisms: a synergy of concepts. Integr Comp Biol 42:771775

Widdows J (2001) The intertidal zone. In: Huntley D, Leeks G, Walling D (eds) Land ocean interaction. Measuring and modelling fluxes from river basins to coastal seas. IWA Publishing, London, pp 185-208

Williams GA (1990) The ecologies of the flat periwincles, Littorina obtusata (L.) and L. mariae Sacchi et Rastelli. Field Stud 7:469482 